different rates ; this is also true of the same enzyme in different cells of a multicellular organism. What is known of mitosis, on the other hand, suggests that all genes in a nucleus reproduce at the same rate. Uniless gene reproduction and gene action are totally independent of each other, we have to reconcile the uniformity in reproduction of the genes with the enormous variation in the output of what we believe to be their primary products. This is, of course, one way of looking at the problem of cell differentiation. Two series of important investigations may suggest a way out of this difficulty.

First, there are the findings of Spiegelman and Lindegren in yeast. A dominant gene is necessary for yeast cells to produce the 'adaptive' enzyme melibiozymase. In cells carrying the gene, the enzyme increases in amount with an autocatalytic trend when they are put in a medium containing melibiose; it disappears reversibly in a few hours when melibiose is removed. With appropriate crosses, cells can be obtained lacking the gene but carrying some melibiozymase in the cytoplasm : these cells can go on producing melibiozymase indefinitely, and for an indefinite number of generations, if kept in contact with melibiose; removal of melibiose brings about the irreversible loss of the enzyme.

Secondly, there is Sonneborn's remarkable work on Paramecium, only the essentials of which can be referred to here. Certain strains carry in the cytoplasm a 'kappa' substance which, released into the water, poisons it for other strains. With appropriate crosses, individuals can be obtained with the same genetic constitution as the former but lacking the 'kappa' substance in the cytoplasm. These individuals are unable to produce the 'kappa' substance unless some of it is introduced into the cytoplasm by means of special devices. The production of 'kappa' can also be blocked by suitable gene substitutions. In other words, 'kappa' is produced if some of it is present in the cytoplasm to start with and the genetic constitution is appropriate.

From these investigations and the stimulating discussion, especially by Muller, at the St. Louis Conference, I would like to draw the following very speculative picture. Enzymes, or similar proteins, occur in the cytoplasm, and can increase in amount autocatalytically if a trace is present to begin with. For this increase specific precursors, indirectly controlled by genes, are required. Furthermore, certain of these autocatalytic proteins, being unstable, can be maintained and increase in the cytoplasm only if specific substrates, intra- or extra-cellular, are available. Lastly, while those which are stable, or stabilized by ever-present intracellular substrates, can perpetuate themselves from cell to cell simply through cytoplasmic transmission, those which require a stabilizing extracellular substrate would be continually liable to be lost. There is, however, a safety mechanism : a specific gene keeps a trace of these unstable substances always ready; whenever the external substrate is provided, this trace can start the autocatalytic process independently of the specific gene. What the gene has to do is therefore only to synthesize an initial amount of the substance. Until we can give each its proper chemical status, there is no harm in lumping all these 'self-reproducing' substances, gene-initiated or otherwise, under the name of 'plasmagenes'. Those that can be transmitted externally from one cell to another, and there cause disease, may be viruses, as Darlington suggests. It is noteworthy that pathologists, starting from the virus end of the story, have long held more or less the same view.

Should the preceding picture be broadly correct, the large differences in output of different enzymes in a cell, and of the same enzyme in different cells, would be reconcilable with the view that most enzymes are primary gene products. We may conceive that all genes in a cell are, at any one time, working all at the same rate, say producing the same number of molecules of their different primary products; yet the actual amount of each in the cytoplasm will vary secondarily, depending, among other things, on its ability to increase autocatalytically, on the limiting amount of specific precursor, and on extra- or intracellular substrates. Since the presence of precursors and of intracellular substrates depends on the previous history of the cell, as pointed out by Spiegelman and Lindegren, there is here a basis for cell differentiation in time, each successively available precursor or substrate making possible the indepen. dent autocatalytic increase, and the activity, of new gene-initiated plasmagenes.

On the whole, the nucleus seems to emerge from these studies with enhanced prestige. Its control of the activities of the cell seems to be largely a one-way affair. No doubt the nuclear membrane holds a good deal of the secret, and it would be desirable to stert tackling it.

\section{INTERNATIONAL SCIENTIFIC CO-OPERATION}

\author{
By Prof. F. J. M. STRATTON, O.B.E. \\ General Secretary of the International Council of \\ Scientific Unions
}

7 HE gradual easing of restrictions on travel and on the general release of scientific discoveries has made it practicable once more to arrange international meetings of men of science. The general assembly of the International Council of Scientific Unions will meet in London during July 22-24, 1946. Meanwhile its Executive Committee has held a meeting in London attended by representatives of most of the International Unions adhering to the Council.

In welcoming the Committee at its opening session, Prof. A. V. Hill, foreign secretary of the Royal Society, pointed out that science in its own interest must remain an international concern and that the future of civilization itself depends upon the close co-operation of scientific men throughout the world. Taking as an example the field of medicine and the high ethical principles which have been developed therein, he emphasized the need for a common standard of ethical behaviour in science. "In standards of truthfulness and integrity, in readiness to co-operate with other scientists of good will everywhere, and in refusal to use the common knowledge, prestige and power of science for base, harmful and selfish ends, scientists should feel them. selves bound by an honourable and unbreakable obligation".

The heavy toll of recent years on those prominent in the field of international science was revealed by the list of members of the Committee who had died since its last meeting: Marconi and $J_{0 j i}$ Sakurai, vice-presidents ; Sir Arthur Eddington, president of the International Astronomical Union; Prof. Nicols 
Parravano, president of the International Union of Chemistry; Sir Albert Seward, president of the International Union of Biology; Dr. Philippson, general secretary of the International Union of Physics; and General Bourgeois, former vicepresident, representing the International Union of Geography.

The president of the Council, Prof. C. Fabry, had been compelled to resign on account of ill-health (he has since died, December 11), and Dr. H. R. Kruyt was elected president; Dr. Elmer D. Merrill being elected vice-president in succession to Dr. Kruyt.

The International Council, or rather its predecessor the International Research Council, was created after the First World War and took as its main task the creation of the various international scientific unions. In the early days the Council exercised a certain amount of control over these unions in such questions 8s membership and finances. As the individual unions became established and strong, this control proved irksome, and a change took place in the relative positions of the Council and the unions, largely the work of the then general secretary of the Council, the late Sir Henry Lyons. Now it would be fairer to say that the unions control the Council, the majority of the members of the Executive Committee being the representatives of the unions. The officers and two members of the Executive Committee only are appointed by the General Assembly, at which the national adhering organisations have a preponderating vote.

The international unions meet in general assembly as a rule once in three years for discussions on the field of knowledge lying within their purview; by means of numerous committees of specialists work is carried on between the meetings and is reported on and discussed at the meetings of the general assembly. Ninety-two such committees have been reported as working in the various international unions, their activities covering a very wide field of knowledge. Each union also appoints at its general assembly a small bureau of officers who are able to answer for the union as a whole between meetings. Some of these have been badly broken up during the war years and are only now being rebuilt.

In addition to the 'international unions', there are in existence a number of 'international congresses' which meet from time to time in different countries but have no continuity of active existence between meetings. Broadly speaking, it would be safe to say that those who have been actively concerned with these congresses and have pleasant recollections of their scientific discussions and fellowship do not desire to change them into international unions. The weakness of their position, however, is the lack of a body between meetings that can answer for the subject covered by the congress and that can nominate the most suitable members for co-operation with unions desiring their help. Border-line subjects needing international study are catered for by joint commissions between the various unions. It would be a help if an international congress would appoint a bureau, to function between meetings, to which the various requests for assistance or advice could be addressed. This is done in some cases already. In other cases union and congress both exist. The general assembly of the union meets at the same place as the congress and within a day or two of the congress meeting. Elasticity of organisation is desirable to meet the different needs and outlook of workers in different fields.
Joint commissions of the unions have been active for more than twenty years in some cases; for example, the joint commissions on latitude variation, on the determination of longitudes by wireless and on the Bureau de l'heure, in which both the Unions of Astronomy and of Geodesy and Geophysics are concerned. Some joint commissions are only planned as yet; for example, a commission on ionospheric research which it is hoped to set up in due course with members from the Unions of Astronomy, Geodesy and Geophysics, Radio-Science and Physics. Other joint commissions proposed at the recent meeting of the executive committee of the Council are on oceanography (Biology and Geodesy and Geophysics), physico-chemical constants (Physics and Chemistry), viscosity (Chemistry, Biology, Geodesy and Geophysics). In the work of this latter commission it is hoped that means will be found to secure the co-operation of the International Congress of Applied. Mechanics.

In addition to joint commissions between the uninns, which the Council may help to arrange, the Council also appoints committees of its own such as the Committee on Solar and Terrestrial Relationship, in which are members from the Unions of Astronomy and of Geodesy and Geophysics. Another committee of the Council is one on science and social relations (C.S.S.R.) appointed in 1937 to survey the most important results obtained and the directions of progress that are opening and of points of view brought forward in the physical, chemical and biological sciences, with reference to their interconnexion, the development of the scientific picture of the world and their practical application in the life of the community. In response to the inspiring and untiring energy of Prof. J. M. Burgers, secretary of this Committee, reports were being received from countries and unions in the years 1938-39 in readiness for collation and publication, when the outbreak of war interrupted the work ; some of these reports, such as one on the social aspects of science in Estonia, have become of historical interest only. The Committee has now been asked to prepare a survey of the published views of scientific bodies on the problems now arising in connexion with researches into such matters as nuclear physics and drugs. Such a survey may enable the Council to make a reasoned pronouncement, supported by the full weight of international science, on the ethical problems which face scientific men in particular to-day, thus accepting the challenge offered by Prof. Hill to the Executive Committee in his address of welcome at its recent meeting. A valuable contribution to the work of the C.S.S.R. will be provided by the annual reports on the work of the various unions, which the Council hopes to receive in future and to distribute widely.

The Council is linked by a convention to the International Organisation for Intellectual Co-operation of the League of Nations; the convention defines the separate spheres of action of the two bodies and the various ways in which each can help the other. While the fate of the International Organisation of the League of Nations is uncertain at present, there has come into existence the United Nations Educational, Scientific and Cultural Organisation. At the recent conference at which this body was formed, a resolution was adopted, on the proposal of the delegation from the United States, asking the preparatory commission to invite its executive committee to examine with the International Council of Scientific Unions such methods 
of collaboration as might be practicable to strengthen the programmes of the two organisations within the limits of their joint concern; the Executive Com. mittee of the Council has appointed a committee to consult with representatives of the new Organisation, and it is hoped that much may arise from their discussion to the mutual advantages of both bodies. The clause introducing this resolution may well be taken as defining the task now facing the International Council of Scientific Unions :

"Il est urgent de reconstituer et de développer les moyens permettant aux savants de tous les pays d'échanger des renseignements et de travailler en commun au développement de la science et à son utilisation au service de l'humanité".

\section{OBITUARIES}

\section{Andrei Petrovich Semenov-Tian-Shanski}

THE whole development of insect taxonomy and biogengraphy in Russia during the last half-century has been most closely connected with the name of A. P. Semenov-Tian-Shanski, whose death from pneumonia during the blockade of Leningrad in 1942 has now been reported.

Andrei Petrovich was born on June 9, 1866, the son of the famous geographer, Peter Semenov, who was later granted the addition Tian-Shanski to his name as a tribute to his exploration of the Central Asian ranges. The father's love of Nature and serious interest in its study were inherited by the son, who published his first scientific paper while still a student at the University of St. Petersburg, from which he graduated in 1889. This paper was the forerunner of a long series (more than 250) of works on entomology, many of them monographic in character. The official career of Andrei Petrovich was brief, as he was on the scientific staff of the Zoological Museum of the Academy of Sciences only for a short period $(1890-96)$ and then again some years before his death. As he had, however, considerable private means, he was able to devote himself entirely to his scientific work.

Semenov's main interest was the taxonomy of the Coleoptera, but no less outstanding were his contributions to the systematics of the Hymenoptera (particularly Chrysididæ and Siricidæ) and the Dermaptera. His renown as a taxonomist was not due merely to the large number of descriptions (some eight hundred new species, about a hundred new genera and one new family), but also to their unique precision, combined with a profound critical appreciation of the value of morphological characters, which he never studied on a 'type' but always on a large series of specimens. Theoretical problems of taxonomy attracted him strongly, and in 1910 he produced a paper on the limits of species and of lower taxonomic categories, where morphological, phylogenetic and biogeographical criteria were used to define the categories and to represent them as phases of a dynamic system of organisms in process of evolution.

Biogeographical and evolutionary aspects always loomed largely in Semenov's taxonomic work, and many of his masterful monographs have a much wider interest than for specialists in the particular group. His contributions to the zoogeography of Central Asia are particularly noteworthy, and his erowning achievement was a zoogeographical map of the Palæarctic Region published in 1936.

As a president of the Russian Entomological Society for most of his life; joint founder of the Revue Russe d'Entomologie; initiator and most active mem. ber of the Biogeographical Commission of the Russian Geographical Society; and one of the most prolific writers on entomology, Semenov had a profound influence on the development of Russian entomology. A large number of insect taxonomists and biogeographers now working are proud to call themselves his pupils, though he never taught except by example and by incisive criticism of published papers in his many reviews. He was also a most conscientious correspondent, and I was one of the many who derived great benefit from his thorough, and often very outspoken, discussions of scientific problems submitted to him.

Most entomologists tend to be one-sided specialists, but A. P. Semenov, with his aristocratic, highly cultured background, was anything but narrow in his interests. Protection of Nature; organization of museums ; geographical exploration; game lawssuch was the range covered by his writings in the technical and general Press. A problem that par. ticularly attracted his attention was that of the Russian Navy, and he was even elected in 1914 the president of the Russian Naval League. His most serious hobby, however, was the study of the classics, and he specialized in verse translations of Horace. $\mathrm{His}$ knowledge of classical languages found its use in diagnoses of insects, which are written not in the usual 'entomological Latin', but in a Latin which is beyond most entomologists. In the later years of his life, when he had almost lost his sight, he concentrated on the theory of verse, and wrote a book on Pushkin's life and poetry.

Although he travelled abroad only once, when young, Semenov-Tian-Shanski was probably the bestknown Russian entomologist in every country of the world. He was an honorary fellow of the Royal Entomological Society of London and of the Prague Entomological Society; life-member of the Société Entomologique de France; and of course honorary member of a score of Russian entomological and natural history societies.

Vast private entomological collections (more than 700,000 specimens, including hundreds of types), library and archives were all presented by Semenov during his life to the Academy of Sciences.

\section{B. P. Uvarov.}

\section{Mr. Alfred Lucas, O.B.E.}

THE death of Mr. Alfred Lucas at Luxor on December 10, at the age of seventy-six, marks the close of many years of useful service to chemistry and archæology. His scientific career began with the analysis of foods and drugs at the Government Laboratory, London; but persistent ill-health forced him, after several years, to withdraw to the warmer climate of Egypt. Recovered somewhat, he joined the Egyptian Government service and in time became responsible for the Survey Department Laboratory which, under his able direction, developed beyond recognition. From a concern devoted prim. arily to the analysis of minerals, it became the Chemical Department of the Ministry of Finance, embodying the Assay Office and the petroleum refinery at Suez. By the routine testing of materials in this laboratory, considerable economies were 